\title{
Are Sacred Groves of Kathmandu Valley Efficient in Sequestering Carbon?
}

\author{
L. J. Shrestha, ${ }^{1}$ M. P. Devkota, ${ }^{1}$ and B. K. Sharma ${ }^{2}$ \\ ${ }^{1}$ Department of Botany, Amrit Campus, Thamel, P.O. Box 102, Kathmandu, Nepal \\ ${ }^{2}$ Department of Natural Resource Management, Phokhara University, Kathmandu, Nepal \\ Correspondence should be addressed to L. J. Shrestha; joshi.laxmi.shrestha@gmail.com
}

Received 4 October 2015; Revised 1 February 2016; Accepted 10 February 2016

Academic Editor: Muhammad Iqbal

Copyright (C) 2016 L. J. Shrestha et al. This is an open access article distributed under the Creative Commons Attribution License, which permits unrestricted use, distribution, and reproduction in any medium, provided the original work is properly cited.

\begin{abstract}
Ability of plant to fix atmospheric carbon dioxide and store it in biomass is contributing to global carbon cycle. Sacred groves, one of the regimes for forest management, play role in regulating climate by acting as sinks for carbon. Aiming to assess sequestrated carbon in tree the study was conducted in two sacred groves of Kathmandu valley, Nepal. Concentric circular plots of $20 \mathrm{~m}$ radius were used for data collection. Allometric equation having height, diameter, and specific gravity of tree was used to determine biomass. The calculated biomass of tree was converted to the carbon stock by using carbon fraction. Tree species of both sacred groves sequestered 15.08 metric tons of carbon. The carbon stock was high in Quercus-Myrsine forest and low in Schima-Pyrus forest.
\end{abstract}

\section{Introduction}

Carbon sequestration is the process of capturing and longterm storage of atmospheric carbon dioxide $\left(\mathrm{CO}_{2}\right)$ in the biosphere. Carbon is one of the essential elements of life and green plants have unique ability to assimilate it in the form of carbon dioxide as raw material for food preparation [1]. Thus, forests play a key role in climate change; both sinks and sources of carbon dioxide [2] and the rate of sequestration depend on the growing stages of tree. The rate is highest in young age of trees between 20 and 50 years [3]. Aboveground biomass of woody vegetation is one of the largest carbon pools. Above-ground biomass is determinant to the ecosystem's potential for carbon storage. Forest trees are contributing to reduce atmospheric $\mathrm{CO}_{2}$ concentration by accumulating it as biomass [4]. This plays an important role in regulating the concentration of atmospheric $\mathrm{CO}_{2}$ and global climate change [5].

Forest management regimes in Nepal include eleven different types and sacred groves, also called religious forest, which is one among them. Sacred groves are a patch of forest protecting rich biodiversity and conserved by local people based on their indigenous cultural, religious belief, and taboos [6]. In Nepal, there are culturally rich local societies of Kathmandu valley having traditionally managed sacred groves as a result of their strong belief and taboos associated with religion. Sacred groves, which are managed by the local communities, are also playing a significant role in the conservation of plant biodiversity. The study aims to analyze the efficiency of these forest trees in sequestering carbon. This will be a good basis to the incentive provisioned for Reducing Emission from Deforestation and Forest Degradation (REDD) mechanism.

In this study, two sacred groves of Kathmandu valley in midhill physiographic zone of Central Development Region of Nepal were selected. The first one is located in the oldest and most famous religious site of Hindu culture, called as Pashupati Sacred Grove (PSG), belonging to Lord Pashupatinath Temple. This site covers an area of $83.55 \mathrm{ha}$ and is located in $27^{\circ} 42^{\prime} 25^{\prime \prime}-27^{\circ} 42^{\prime} 36^{\prime \prime} \mathrm{N}$ latitude and $85^{\circ} 20^{\prime} 12^{\prime \prime}-85^{\circ} 21^{\prime} 29^{\prime \prime} \mathrm{E}$ longitude at $1,300 \mathrm{~m}$ elevation. Pashupati Area Development Trust, a government organization, has undertaken the management responsibility of this grove. The second is Bajrabarahi Sacred Grove (BSG) located at southeast corner of Kathmandu valley, in Chapagaun Village Development Committee (VDC) of Lalitpur district. It is located at 1,440 m elevation between $27^{\circ} 36^{\prime} 15.88^{\prime \prime}-27^{\circ} 36^{\prime} 24.62^{\prime \prime} \mathrm{N}$ latitude and $85^{\circ} 19^{\prime} 40.58^{\prime \prime}-85^{\circ} 19^{\prime} 50.59^{\prime \prime}$ E longitude covering 18.29 ha area. 
Community based organization called Joytidaya Sangh is managing this grove. These areas are located in subtropical monsoonal climatic zone. The average annual temperature becomes maximum $\left(31.9^{\circ} \mathrm{C}\right)$ during June and minimum during the months of December $\left(2.0^{\circ} \mathrm{C}\right)$. The average relative humidity ranged between $70 \%$ and $86 \%$. The average annual rainfall exceeds more than $1480.4 \mathrm{~mm}$ and about $80 \%$ of rainfall occurs during the monsoon season (June to September) [7]. The study area is characterized with 4 distinct seasons, spring (March-May), summer (June-August), autumn (September-November), and winter (December-February).

\section{Materials and Methods}

Data for tree level characteristics were collected from concentric circular plots [8] established in parallel transects of $150 \mathrm{~m}$ apart from each other traversing north-south direction, with the help of Google earth image. Tree level characteristics like height and diameter at breast height $(\mathrm{DBH})$ of each tree inside the concentric circular plot were collected. Plots were constructed at $100 \mathrm{~m}$ interval within each transect and established $25 \mathrm{~m}$ inside the forest margin to reduce the edge effect.

Plot center of each CCP was identified by using Geographic Position System (GPS) incorporating already identified coordinates from Google Earth images. The CCP consists of four circular plots: plot with the radius of $20 \mathrm{~m}$ $\left(\right.$ area $\left.=1257.1 \mathrm{~m}^{2}\right)$ all big size trees with $\mathrm{DBH} \geq 30 \mathrm{~cm}$ were measured; plot with the radius $15 \mathrm{~m}\left(\right.$ area $\left.=707.1 \mathrm{~m}^{2}\right)$ trees with DBH $20.0-29.9 \mathrm{~cm}$ were measured; the third plot with the radius $8 \mathrm{~m}\left(\right.$ area $\left.=201.1 \mathrm{~m}^{2}\right)$ trees with DBH from $10.0 \mathrm{~cm}$ to $19.9 \mathrm{~cm}$ were measured; and fourth plot with the radius $4 \mathrm{~m}$ $\left(\right.$ area $\left.=50.2 \mathrm{~m}^{2}\right)$ trees with DBH from $5.0 \mathrm{~cm}$ to $9.9 \mathrm{~cm}$ were measured. The height and DBH of trees (woody plant with single bole, $\geq 5 \mathrm{~cm} \mathrm{DBH}$ and $>1.3 \mathrm{~m}$ height) were measured with the help of Vertex IV with Transponder T3 and diameter tape, respectively.

Importance values index (IVI) of individual trees species recorded in the particular vegetation was calculated by adding the relative values of frequency, density, and dominance [9]. Name of each forest type was determined by ordering the importance values of recorded tree species. Maturity index [10] of forest community was calculated, which is the ratio of sum of frequencies of individual species in the habitat and total number of species in the habitat.

The Shannon-Weiner species diversity index [11] was calculated by using the following formula:

$$
H=-\sum_{i=1}^{s}\left(p_{i}\right)\left(\log p_{i}\right),
$$

where $H$ is Shannon index of species diversity, $p_{i}$ is proportion of total number of individual of species $i$, and $s$ is number of species.

Evenness was calculated by dividing Shannon-Weiner diversity index with the log value of total number of species found in the area. Amount of carbon in tree species was calculated from the above-ground biomass. Above-ground biomass of trees was analyzed by using allometric equation
TABLE 1: Carbon stock density in the trees of different forests.

\begin{tabular}{lc}
\hline Forest type & Carbon stock (ton) \\
\hline Schima-Pyrus forest (PSG) & 113.98 \\
Myrsine-Persea forest (PSG) & $2,602.83$ \\
Quercus-Myrsine forest (PSG) & $12,221.85$ \\
Neolitsea cuipala forest (BSG) & 145.68 \\
Total & $\mathbf{1 5 , 0 8 4 . 3 4}$ \\
\hline
\end{tabular}

which includes information about $\mathrm{DBH}$ in $\mathrm{cm}$, tree height in $m$, and wood specific gravity in $\mathrm{g} \mathrm{cm}^{-3}$ [12]. The climate of the study areas is moist, with $1480 \mathrm{~mm}$ average annual rainfall, and has subtropical evergreen forests; the following allometric equation developed by Chave et al. [13] was appropriate to use for the analysis of above-ground tree biomass (AGTB):

$$
\text { AGTB }=0.0509 \rho D^{2} H,
$$

where AGTB is above-ground tree biomass $(\mathrm{kg}), \rho$ is wood specific gravity $\left(\mathrm{g} \mathrm{cm}^{-3}\right), D$ is tree diameter at breast height (cm), and $H$ is tree height (m).

The wood specific gravity was extracted from published literatures $[14,15]$. The biomass stock densities were converted to carbon stock densities by using the IPCC (2006) [16] carbon fraction of 0.47 . Root-to-shoot ratio value of $1: 5$ (20\% of AGTB) was used to find below-ground biomass [17]. Total carbon stock density of tree in particular vegetation was calculated by summing up above-ground and belowground carbon stock. Weight of carbon in the tree was multiplied by 3.67 to determine the weight of carbon dioxide sequestered [18]. Analysis of variance was conducted to determine the mean difference between species richness, diversity index, evenness, and maturity index. Paired $t$-tests were used to compare carbon with species richness, diversity index, evenness, and maturity index.

\section{Results}

On the basis of importance value, three types of forest namely Schima-Pyrus, Myrsine-Persea, and Quercus-Myrsine were recorded in PSG, whereas single forest type, Neolitsea cuipala, was identified in BSG [19]. Trees species of PSG and BSG together sequestered 15,084.34 tons of carbon. The highest amount of average carbon (12,221.85 ton) was sequestered by Quercus-Myrsine forest followed by MyrsinePersea (2602.83 ton) forest. The lowest carbon stock was recorded from Schima-Pyrus forest, 113.98 ton (Table 1).

3.1. Schima-Pyrus Forest. In this forest, Schima wallichii was found to be the most important tree species $(I V I=81.4$ ) followed by Pyrus pashia (IVI $=51.5$ ). There were 14 species of trees with the population of 319 individuals per hectare. Average tree height of this forest was $15.2 \pm 7.8 \mathrm{~m}$ and average DBH was $40.9 \pm 18.2 \mathrm{~cm}$. Average carbon stock density of each species of tree in this forest was 5.45 ton ha ${ }^{-1}$. This forest sequestrated 1595.75 tons of total carbon and Schima wallichii was the most $\left(51.68\right.$ ton ha $\left.{ }^{-1}\right)$ carbon sequestering 
tree followed by Persea odoratissima (10.41 ton ha ${ }^{-1}$ ) and Araucaria bidwillii (3.59 ton ha ${ }^{-1}$ ) (Table 2). The total carbon dioxide sequestration by this forest was 5.86 metric ton.

3.2. Myrsine-Persea Forest. The dominant tree of this forest was Myrsine capitellata (IVI $=142.0)$ followed by Persea odoratissima (IVI $=38.9$ ). Eleven tree species were found in this forest; their average height and $\mathrm{DBH}$ were $11.7 \pm$ $5.0 \mathrm{~m}$ and $30.7 \pm 17.4 \mathrm{~cm}$, respectively. This forest includes 603 individual trees per hectare. The total carbon stock density of the trees species in this forest was 28631.17 ton and average carbon stock density of each tree species in this forest was 115.68 ton ha $^{-1}$. In this forest Schima wallichii was the most carbon sequestrating (359.06 ton ha ${ }^{-1}$ ) species followed by Myrsine capitellata $\left(212.56\right.$ ton ha $^{-1}$ ) (Table 2). Total carbon dioxide sequestrated in this forest was 105.08 metric ton.

3.3. Quercus-Myrsine Forest. The dominant tree species of this forest was Quercus glauca (IVI = 138.5) followed by Myrsine capitellata (IVI = 56.2). In this forest five tree species were recorded; their average height and DBH were $12.6 \pm$ $5.1 \mathrm{~m}$ and $28.5 \pm 13.7 \mathrm{~cm}$, respectively. The number of stems reported from this forest was 677 individuals per hectare. Average carbon stock density in the tree species of this forest was 304.78 ton ha ${ }^{-1}$ and carbon stock was 61109.27 ton. In this forest Schima wallichii was more carbon sequestrating tree species ( 821.52 ton ha $^{-1}$ ) followed by Quercus glauca (321.52 ton ha ${ }^{-1}$ ) (Table 2). Total carbon dioxide sequestrated by the tree species of this forest was 224.27 metric ton.

3.4. Neolitsea Cuipala Forest. In this forest 18 tree species were recorded. Among the reported tree species Neolitsea cuipala was dominant tree (IVI $=111.3$ ) followed by Castanopsis indica $(\mathrm{IVI}=36.9)$. The average height and $\mathrm{DBH}$ of the reported trees in this forest were $18.6 \pm 12.7 \mathrm{~m}$ and $36.6 \pm$ $19.4 \mathrm{~cm}$, respectively. This forest included 432 individual trees per hectare. Total carbon stock density of tree species in this forest was 143.37 ton ha $^{-1}$ and the average carbon stock density of each tree species was 7.96 ton ha $^{-1}$. The higher carbon was sequestrated by Neolitsea cuipala ( 49.71 ton ha ${ }^{-1}$ ) followed by Castanopsis indica (31.29 ton $\mathrm{ha}^{-1}$ ) (Table 2). Total carbon dioxide sequestrated in this forest was 9.62 metric ton.

3.5. Species Richness and Carbon Stock. In Neolitsea cuipala forest of BSG, the number of tree species was higher $(n=$ 18) but less than amount of carbon stock (143.37 ton ha ${ }^{-1}$ ) in comparison to other forest types of PSG, whereas in Quercus-Myrsine forest of PSG the carbon stock was highest $\left(1523.92\right.$ ton ha $\left.^{-1}\right)$ and the number of tree species was found to be lowest $(n=5)$. The lowest carbon stock was recorded from Schima-Pyrus forest $\left(76.35\right.$ ton $\left.\mathrm{ha}^{-1}\right)$ whereas the tree species richness was high $(n=14)$. In Myrsine capitellata forest the number of tree species was 11 with carbon stock density 1272.49 ton ha $^{-1}$ (Table 3). The available number of tree species significantly affects the carbon sequestration of the forest of study area $(t=1.98, p<0.05, \mathrm{df}=6)$.

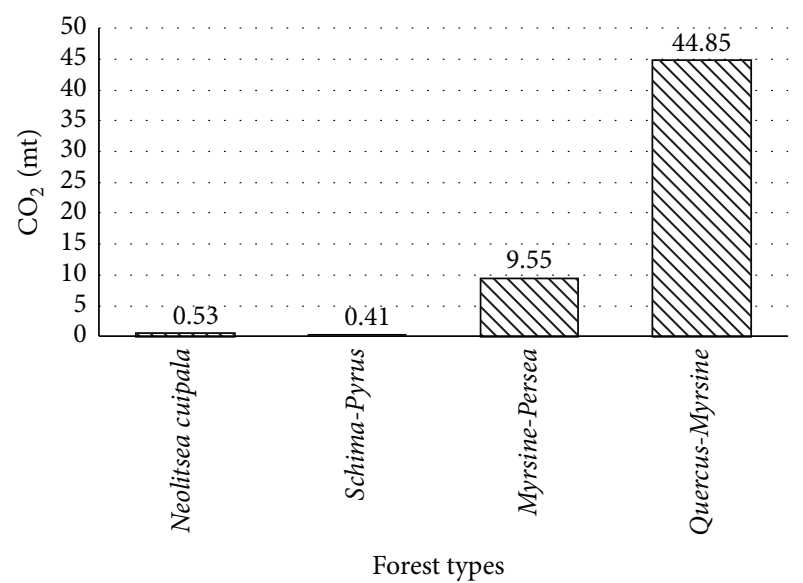

FIgURE 1: Total amount of carbon dioxide assimilation by trees in different forests.

3.6. Diversity, Evenness, and Carbon Stock. In both studied sites Schima-Pyrus forest was found to be more diverse than other forest types. In this forest Shannon-Wiener diversity index was found to be highest (1.84) but carbon stock was lowest $\left(76.35\right.$ ton $\left.\mathrm{ha}^{-1}\right)$. In Quercus-Myrsine forest carbon stock was found to be highest $\left(1523.92\right.$ ton $^{-1}$ ) but the diversity index was found to be lowest (1.19). In Neolitsea cuipala forest the carbon stock was 143 ton $\mathrm{ha}^{-1}$ and diversity index was 1.80. Similarly, in Myrsine-Persea forest carbon stock was 1272.49 ton ha $^{-1}$ and diversity index was 1.35 (Table 3). There was significant effect of diversity index in carbon stock of the forest in the study area $(t=2.00, p<0.05, \mathrm{df}=6)$.

Evenness value indicates that the available tree species in Quercus-Myrsine forest were more evenly distributed (0.74) than other forest types. The carbon stock was found to be highest $\left(1,523.92\right.$ ton $\left.^{-1}\right)$ in this forest. Tree species in $M y r$ sine-Persea forest were less evenly distributed (0.56) but carbon stock was found to be high (1,272.49 ton ha $\left.{ }^{-1}\right)$. In SchimaPyrus forest the carbon stock was lowest $\left(76.35\right.$ ton ha $\left.{ }^{-1}\right)$ with high evenness value (0.70). In Neolitsea cuipala forest the carbon stock was found to be 143.37 ton ha ${ }^{-1}$ and evenness was 0.62 (Table 3 ). The evenness of tree species significantly affect the available carbon stock of the forest in the study area $(t=2.01, p<0.05, \mathrm{df}=6)$.

3.7. Maturity and Carbon Stock. Maturity index of QuercusMyrsine forest was found to be highest (80.0) with highest carbon stock (1523.92 ton $\mathrm{ha}^{-1}$ ). Similarly, the maturity index of Schima-Pyrus forest was found to be lowest (29.4) with lowest carbon stock $\left(76.35\right.$ ton ha $\left.^{-1}\right)$. The maturity indices in Myrsine-Persea and Neolitsea cuipala forests were 43.6 and 33.9 with their carbon stocks 1272.49 ton $\mathrm{ha}^{-1}$ and 143.37 ton $\mathrm{ha}^{-1}$, respectively (Table 3 ). There were no significant effects of maturity index $(t=1.88, p<0.05, \mathrm{df}=6)$ and carbon sequestration.

3.8. Carbon Dioxide Assimilation. It was found that the trees species of both study sites assimilate 55.34 metric tons of average carbon dioxide. The highest amount of carbon 
TABLE 2: Carbon stock (per ha) of trees in different forests of the study area.

\begin{tabular}{|c|c|c|c|c|c|}
\hline \multirow{2}{*}{$\mathrm{SN}$} & \multirow{2}{*}{ Tree species } & \multicolumn{4}{|c|}{ Forest types } \\
\hline & & Schima-Pyrus & Myrsine-Persea & Quercus-Myrsine & Neolitsea cuipala \\
\hline 1 & Albizia julibrissin Durazz. & - & - & - & 0.90 \\
\hline 2 & Albizia lebbeck (L.) Benth. & - & - & - & 0.43 \\
\hline 3 & Alnus nepalensis D. Don & 0.34 & - & - & \\
\hline 4 & Areca catechu $\mathrm{L}$. & - & - & - & 1.24 \\
\hline 5 & Araucaria bidwillii Hook. & 3.59 & - & - & \\
\hline 6 & Castanopsis indica (Roxb.) Miq. & - & - & - & 31.29 \\
\hline 7 & Castanopsis tribuloides (Sm.) A. DC. & 0.09 & 139.74 & - & 5.37 \\
\hline 8 & Cassia fistula $\mathrm{L}$. & - & - & - & 3.45 \\
\hline 9 & Celtis australis $\mathrm{L}$. & 2.02 & - & - & 0.54 \\
\hline 10 & Choerospondias axillaris (Roxb.) Burtt \& Hill. & - & 64.63 & - & 13.74 \\
\hline 11 & Eurya acuminate DC. & 0.11 & - & - & \\
\hline 12 & Hymenodictyon excelsum (Roxb.) Wall. & 0.12 & - & - & 0.48 \\
\hline 13 & Myrica esculenta Buch.-Ham. ex D. Don & - & 23.64 & - & 1.75 \\
\hline 14 & Myrsine capitellata Wall. & 0.96 & 212.56 & 139.87 & 2.03 \\
\hline 15 & Myrsine semiserrata Wall. & - & 8.44 & - & 0.73 \\
\hline 16 & Neolitsea cuipala (Buch.-Ham. ex D. Don) Kosterm. & - & - & - & 49.71 \\
\hline 17 & Persea odoratissima (Ness) Kosterm. & 10.41 & 198.40 & 220.39 & 0.52 \\
\hline 18 & Pyrus pashia Buch.-Ham. ex D. Don & 2.24 & 21.96 & - & \\
\hline 19 & Quercus glauca Thunb. & 2.28 & 38.62 & 321.52 & \\
\hline 20 & Rhus succedanea L. & - & - & - & 0.64 \\
\hline 21 & Sapium insigne (Royle) Benth. ex Hook.f & - & - & - & 0.57 \\
\hline 22 & Schima wallichii (DC.) Korth. & 51.68 & 359.06 & 821.52 & 27.02 \\
\hline 23 & Stranvaesia nussia (D. Don) Decne. & 0.36 & 30.07 & - & \\
\hline 24 & Syzygium cumini (L.) Skeels. & 1.94 & 175.38 & 20.63 & 2.96 \\
\hline 25 & Ziziphus incurva Roxb. & 0.22 & - & - & \\
\hline
\end{tabular}

TABLE 3: Species richness, diversity, evenness, maturity, and carbon stock density in the trees of different forests.

\begin{tabular}{lccccc}
\hline Forest type & Number of species & Shannon diversity & Evenness & Maturity index Carbon stock (ton ha $^{-1}$ ) \\
\hline Schima-Pyrus & 14 & 1.84 & 0.70 & 29.4 & 76.35 \\
Myrsine-Persea & 11 & 1.35 & 0.56 & 43.6 & 1272.49 \\
Quercus-Myrsine & 5 & 1.19 & 0.74 & 80.0 & 1523.92 \\
Neolitsea cuipala & 18 & 1.80 & 0.62 & 33.9 & 143.37 \\
\hline
\end{tabular}

dioxide was sequestrated in Quercus-Myrsine forest which sequestered 44.85 metric tons of carbon dioxide. The lowest sequestration of carbon dioxide was found in Schima-Pyrus forest. This forest sequestrated 0.41 metric ton of carbon dioxide in the trees (Figure 1).

\section{Discussions}

The sequestrated carbon in the forest varied according to the forest type and density of trees. Species composition of the forest also differs in the average amount of assimilated carbon in the particular forest type. Trees of PSG and BSG sequestrated 15,084.34 ton of carbon and 55.34 metric ton of carbon dioxide, respectively. The highest amount of carbon stock (12221.85 ton) and $\mathrm{CO}_{2}(44.85 \mathrm{mt})$ was accumulated in Quercus-Myrsine forest due to having larger tree and higher density $\left(n=677 \mathrm{ha}^{-1}\right)$. In this study area Schima wallichii (821.52 ton $\mathrm{ha}^{-1}$ ) was highest carbon sequestrating tree species (Table 2). Similar study conducted in the forest of Far Western Terai physiographic region of Nepal recorded average tree biomass of 186.6 ton $^{-1}$ and Shorea robusta exhibited the highest biomass of 89.8 ton $\mathrm{ha}^{-1}$, followed by Terminalia tomentosa 41.0 ton $\mathrm{ha}^{-1}$, with one forest type Shorea robusta [20]. Similar kind of study was conducted in buffer zone community managed forest of Chitwan National Park at central lowland Nepal. Trees of that buffer zone community forest had sequestered 3333.7 tons of carbon and 12.1 metric ton carbon dioxide. The highest amount of carbon (1206.9 ton) and $\mathrm{CO}_{2}(4.4 \mathrm{mt})$ was accumulated by Dalbergia sissoo forest. The highest carbon sequestrating tree was Dalbergia sissoo (262.5t/ha) [18]. The difference found in the forest category and carbon stocks in between these studies were due to difference in physiographic region, species composition, and wood density of tree species. In the present study there is significant difference $(F=13.42$, $\alpha=0.05, \mathrm{df}=3,12)$ of the mean among species richness, 
diversity index, evenness, and maturity index of the studied forest.

Study about the carbon stock conducted in BSG with the sampling intensity of $0.6 \%$ recorded 1011 ton ha ${ }^{-1}$ of carbon stock. Among reported six major tree species, the average carbon stock was high in Schima wallichii $\left(429.5\right.$ ton ha $^{-1}$ ) followed by Castanopsis indica $\left(19\right.$ ton $^{-1}$ ) [21]. The present study conducted in same area with sampling intensity of 6.9\% and recorded carbon stock density (143.37 ton ha ${ }^{-1}$ ) was lower than that of previous study [21]. The reported tree species were found to be higher $(n=18)$ in current study.

Generally around the world there is positive relationship between biodiversity and carbon stock [2]. Similar result was reported in the collaborative forest of low land Terai region of Nepal [22]. The current study also showed significant effect of diversity index in carbon stock of the forest $(t=2.00, p<$ $0.05, \mathrm{df}=6$ ).

The maturity index of forest community of the study area was higher in the Quercus-Myrsine forest. The largest girth sized and tallest Schima wallichii trees were the main carbon sink in this forest (Table 2). The amount (ton ha ${ }^{-1}$ ) of assimilated carbon in the forest types of study area varied according to the girth size, height, and wood specific gravity of tree species. The more developed plant community has high maturity index [10]. The maturity index is an important indicator for the maturity of plant communities in a specific area and season [23]. In present study the result was based on one time data collection; thus there was no comparison of maturity index in different season. Though the maturity index of forest community has not significantly affected $(t=1.88$, $p<0.05, \mathrm{df}=6)$ the carbon stock in the forest of study area, the carbon stock was found to be highest (1523.92 ton ha ${ }^{-1}$ ) in the forest with higher maturity index in Quercus-Myrsine forest $(\mathrm{MI}=80)$ than the Schima-Pyrus forest $(\mathrm{MI}=29.4)$ of PSG. It showed that mature forest community sequestered higher carbon as indicated by the other study conducted in lowland area of Nepal [18]. However, other studies show that the old growth, mature forest with larger girth size, and taller trees are large carbon pool [24].

\section{Conclusion}

Sacred grove is one of the management regimes applied for the forest conservation in Nepal. In the studied sacred groves three forest types in PSG and one forest type in BSG were recognized based on IVI of tree species. Sequestrated carbon and carbon dioxide were found to be high in Quercus-Myrsine and low in Schima-Pyrus forests of PSG. Amount of carbon sequestration in the studied groves vary according to species composition, density of available trees, and wood specific gravity of tree species. Sacred groves offer safeguarding of forest ecosystems and are also contributing to mitigate climate change through carbon sequestration.

\section{Conflict of Interests}

The authors declare that there is no conflict of interests regarding the publication of this paper.

\section{Acknowledgments}

The study was supported by University Grants Commission of Nepal under the Ph.D. Support Program. The authors are thankful to Pashupati Area Development Trust and Jyotidaya Sangh Bajrabarahi for their encouraging support to carry out research in respective sacred groves. Forest Resource Assessment Nepal is acknowledged for providing survey equipment. They would like to thank Ms. Babita Shrestha and Ms. Rajol Shrestha for helping them during the field works.

\section{References}

[1] V. K. Jain, Plant Physiology, S Chand \& Company, New Delhi, India, 1983.

[2] G. F. Midgley, L. Hannah, D. Millar, M. C. Rutherford, and L. W. Powrie, "Assessing the vulnerability of species richness to anthropogenic climate change in a biodiversity hotspot," Global Ecology and Biogeography, vol. 11, no. 6, pp. 445-451, 2002.

[3] N. Myers and T. J. Goreau, Tropical Forests and the Greenhouse Effect: A Management Response, Discovery Bay Marine Laboratory, University of the West Indies, Discovery Bay, Jamaica, 1991.

[4] B. L. Chavan and G. B. Rasal, "Sequestered standing carbon stock in selective tree species grown in University campus at Aurangabad, Maharashtra, India," International Journal of Engineering Science and Technology, vol. 2, no. 7, pp. 3003-3007, 2010.

[5] D. E. Bunker, F. DeClerck, J. C. Bradford et al., "Species loss and aboveground carbon storage in a tropical forest," Science, vol. 310, no. 5750, pp. 1029-1031, 2005.

[6] A. D. Khumbongmayum, M. L. Khan, and R. S. Tripathi, "Sacred groves of Manipur, northeast India, biodiversity value, status and strategies for their conservation," Biodiversity and Conservation, vol. 14, no. 7, pp. 1541-1582, 2005.

[7] Government of Nepal, Climatological Records of Nepal, Department of Hydrology and Meteorology, Kathmandu, Nepal, 2013.

[8] FRA/DFRS, Terai Forests of Nepal (2010-2012), Department of Forest Research and Survey, Forest Resource Assessment Nepal Project, Kathmandu, Nepal, 2014.

[9] D. B. Zobel, M. J. Behan, P. K. Jha, and U. K. R. Yadav, A Practical Manual for Ecology, Ratna Book Distributors, Kathmandu, Nepal, 1987.

[10] R. E. Pichi-Sermolli, "An index for establishing the degree of maturity in plant communities," The Journal of Ecology, vol. 36, no. 1, pp. 85-90, 1948.

[11] C. E. Shannon and W. Wiener, The Mathematical Theory of Communication, Ulllinois Press, Urbana, Ill, USA, 1963.

[12] H. Petersson, S. Holm, G. Ståhl et al., "Individual tree biomass equations or biomass expansion factors for assessment of carbon stock changes in living biomass-a comparative study," Forest Ecology and Management, vol. 270, pp. 78-84, 2012.

[13] J. Chave, C. Andalo, S. Brown et al., "Tree allometry and improved estimation of carbon stocks and balance in tropical forests," Oecologia, vol. 145, no. 1, pp. 87-99, 2005.

[14] E. R. Sharma and T. Pukkala, Volume Equations and Biomass Prediction of Forest Trees of Nepal, Forest Survey and Statistics Division, Ministry Of Forest and Soil Conservation, Kathmandu, Nepal, 1990. 
[15] A. E. Zanne, G. Lopez-Gonzalez, D. A. Coomes et al., "Global wood density database," Dryad, 2009, http://hdl.handle.net/ 10255/dryad.235.

[16] IPCC, Guidelines for National Greenhouse Gas Inventories, Agriculture, Forestry and other Land Use, vol. 4, Intergovernmental Panel on Climate Change, 2006.

[17] K. G. Mac Dicken, A Guide to Monitoring Carbon Storage in Forestry and Agro-Forestry Projects, Winrock International Institute for Agricultural Development, Little Rock, Ark, USA, 1997.

[18] B. K. Sharma, G. S. Solanki, and M. K. Chalise, "Carbon sequestration in a community managed forest of Chitwan National Park's buffer zone at central lowland Nepal," Bio Journal, vol. 9, no. 1, pp. 46-54, 2014.

[19] L. J. Shrestha, M. P. Devkota, and B. K. Sharma, "Phytosociological assessment of sacred groves in Kathmandu, Nepal," International Journal of Plant \& Soil Science, vol. 4, no. 5, pp. 437-444, 2015, http://www.sciencedomain.org/.

[20] S. K. Gautam, Y. P. Pokharel, K. R. Goutam, S. Khanal, and R. Giri, "Forest structure in the Far Western Terai of Nepal: implications for management," Banko Janakari, vol. 20, no. 2, pp. 21-25, 2011.

[21] K. B. Nepali, B. Pandey, and A. Timilsina, "Carbon stock assessment in Bajrabarahi religious forest of Lalitpur District," Bulletin of Department of Plant Resources, no. 37, pp. 92-96, 2015.

[22] R. A. Mandal, I. C. Dutta, P. K. Jha, and S. Karmacharya, "Relationship between carbon stock and plant biodiversity in collaborative forests in Terai, Nepal," ISRN Botany, vol. 2013, Article ID 625767, 7 pages, 2013.

[23] M. Khan, F. Hussain, and S. Musharaf, "Maturity dynamism of plant life in Tehsil Takht-e-Nasrati, District Karak, Pakistan," International Journal of Biosciences (IJB), vol. 2, no. 3, pp. 6774, 2012.

[24] S. Luyssaert, E.-D. Schulze, A. Börner et al., "Old-growth forests as global carbon sinks,” Nature, vol. 455, no. 7210, pp. 213-215, 2008. 

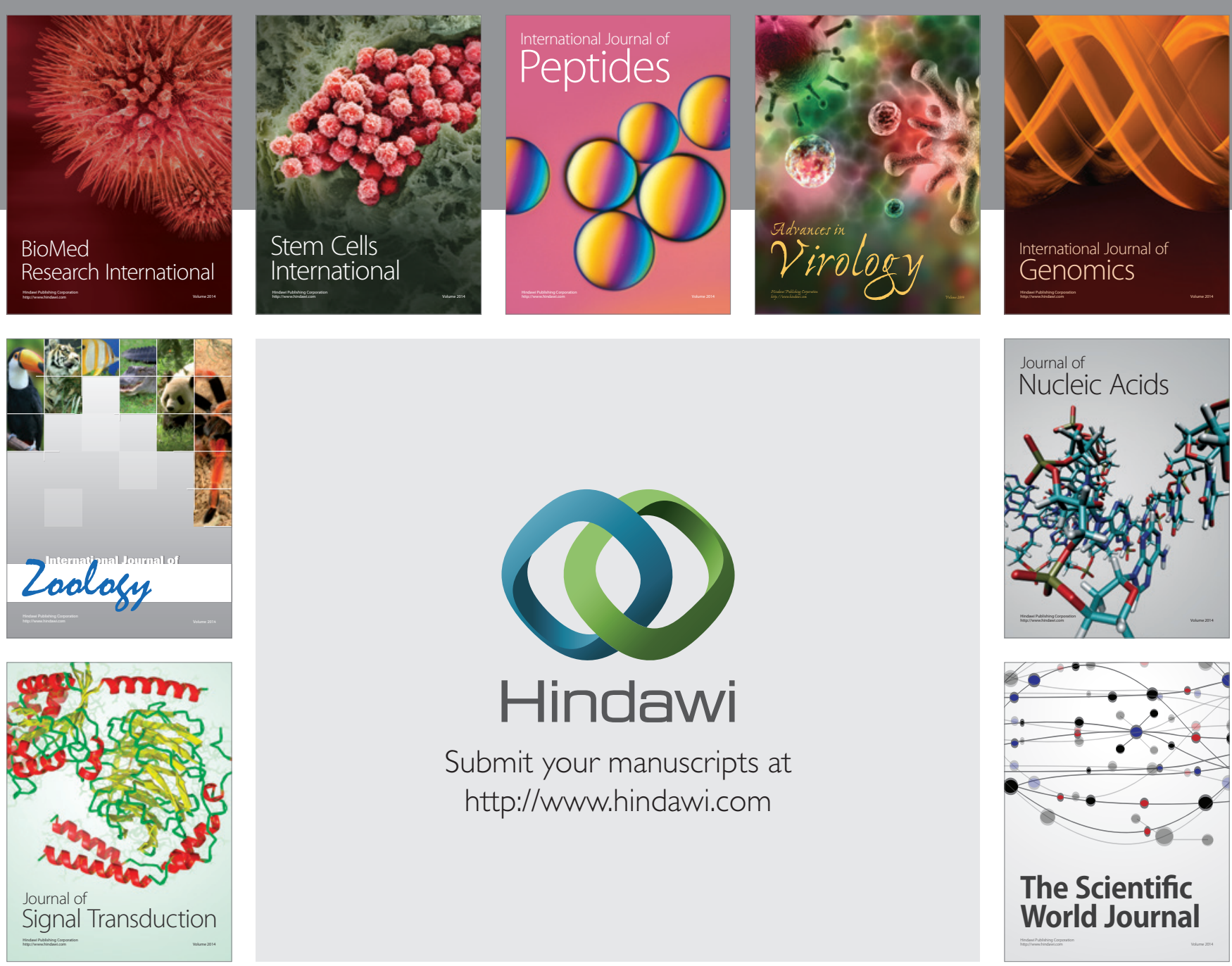

Submit your manuscripts at

http://www.hindawi.com
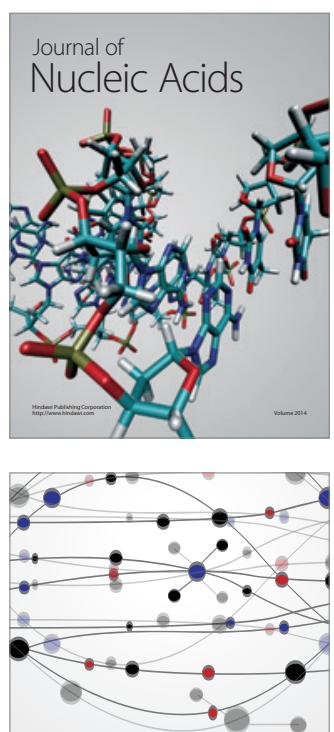

The Scientific World Journal
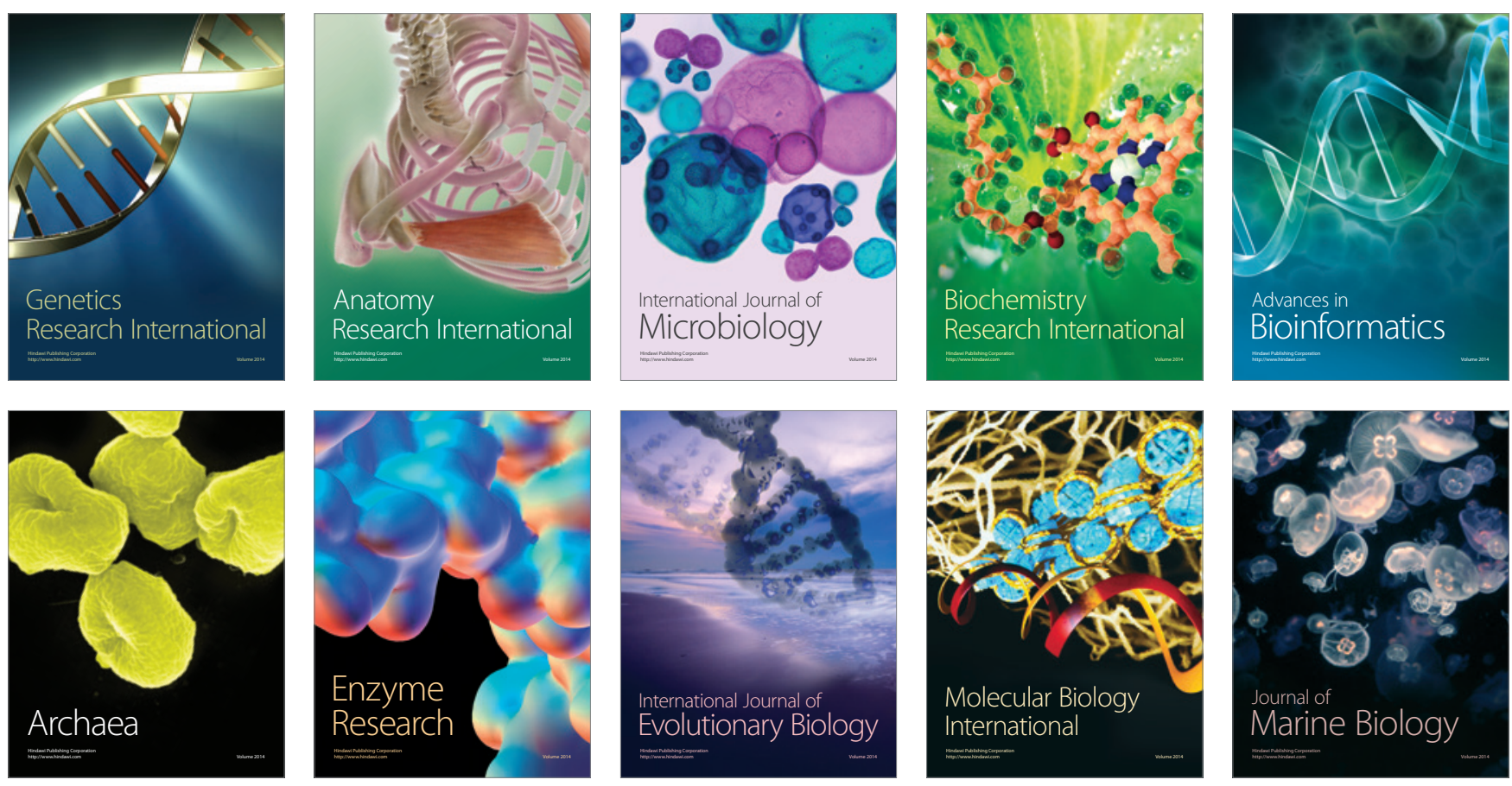